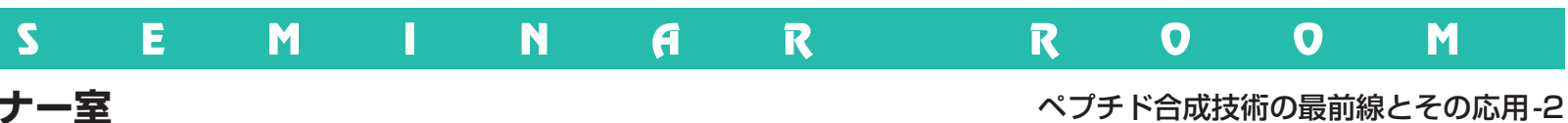

\title{
異常アミノ酸含有ペプチドの合成と応用 異常アミノ酸の連結法
}

\section{今野博行}

山形大学大学院理工学研究科

はじめに

ペプチドを生合成から分類すると，リボソーム系と非 リボソーム系に分けられる。リボソーム系では 20 種類 の正常タンパク性アミノ酸が構成成分であり, ホルモン を代表とするさまざまなぺプチドが生合成される，これ らの構造解析はエドマン分解やマーフィー法などさまざ まな方法が汎用され，さらに現在では質量分析が強力な ッールとして用いられている，化学合成もリボソーム系 ペプチドの組立てを前提に考案され，進化を続けてお り，自動合成機が最も得意とするところである。これら を可能としているのは, タンパク性アミノ酸 20 種類と その誘導体（D-アミノ酸， N-Meアミノ酸など）に限定 されているからであり，あらかじめ標準物質あるいはそ れらのデータ（物性值・分光分析值）を用意できること が強みである。

一方で, 非リボソーム系ペプチドは，一般に異常アミ ノ酸などと呼ばれる非タンパク性アミノ酸を含有する. 異常アミノ酸は数多く存在し，さらに自由に設計できる ためバラエティーが豊富であるが，その入手は一部を除 いて化学合成に頼らざるを得ない，また，これらを含む ペプチドには，SS架橋構造以外にもアミド結合，デプ シ結合（エステル結合）による環状構造や分岐構造，さ らにさまざまな修飾が施されていることが多い，そのた め立体化学を含む構造解析は困難を極める。しかしなが
ら, 難消化性や広範な生物活性をもつものが多数発見さ れ, 医農薬品リード化合物として多くの化学者を魅了し てきた。特に近年ではペプチドリーム社の特殊ペプチド が脚光を浴び，急速に注目が集まっている，そこで今 回，代表的な異常アミノ酸含有ペプチドとその合成法に ついて, 筆者らの研究成果を交えながら紹介したい.

\section{直鎖状異常アミノ酸含有ペプチドとその合成}

\section{1. ペプチドアルデヒドの合成}

ペプチドアルデヒドはペプチドC末端カルボン酸がア ルデヒドに置換されたものを指し，梅沢らによって plasmin や papainに対して強力な阻害能を有するleupeptin $^{(1)}$ ，ならびにantipain ${ }^{(2)}$ が単離され注目を浴びる ようになった． C末端アルデヒドはプロテアーゼの遷移 状態アナログとして活用できるため，その阻害剂として 有用である。一方で，C末端アルデヒドと $\mathrm{N}$ 末端アミン の縮合を経るライゲーションの試みや糖タンパク質の模 倣物の合成に活用された例などが知られる(3). しかしな がら，ペプチドアルデヒドの調製は単純な構造にもかか わらず容易ではない。アルデヒドは一般的に不安定なた め，その変換は合成の終盤に行われる．アルデヒドへの 変換法は大きく2つに分類できる。酸化あるいは還元に よる方法（酸化還元型）と，アセタールやセミカルバゾ ンから変換する方法（アルデヒド等価体型）である. 上 


\section{$\bowtie$ ラム $\bowtie$}

\section{有機合成と天然物}

1828年，ウェーラーによって尿素が化学合成され て以来, 有機合成化学者によって実に多くの化合物 が作られてきました．有機合成化学では石油成分, 糖やアミノ酸などの原料を有用な化合物に変換して いきます，環境污染や化学兵器の開発など反省すべ き過去もありますが, 現在の私たちの生活を支えて くれていることもまた事実です。

一方で天然物（天然有機化合物）の化学には, さら に古い発見以来の歴史があります. 18世紀後半, シューレによるクエン酸や乳酸の単離がその始まり, という説があります. 天然物という名前のとおり天然に 存在する物質ということになりますが, 通常は二次代 謝産物（注釈）を指し, 生物種で共通性が低く, さら に生合成・分泌される組織，時期などが特異的な物質 が研究対象になっています. 古くから天然物をいかに つくるか, という課題のもと有機合成化学が発展して きた歴史もあり, 両者の切っても切り離せない関係が 長く続いています。また，天然物合成はサイエンスと いうだけでなく，芸術的な側面もあり，いつの時代もそ の価值については議論があるように思います，筆者も
過去にいくつかの天然物全合成に立ち会った経験があ りますが，その達成の瞬間には何物にも代え難い感動 を味わいました。

ペプチドはリボソーム系であれば一次代謝産物, 非リボソーム系であれば二次代謝産物に分類される ため, 同じ有機合成化学であっても異なる領域とし て扱われることがあります。特にリボソーム系ペプ チドは，ホルモンや生物毒などさまざま知られ，ま たタンパク質の部分構造という考えから生命科学研 究にニーズが高く, 望むぺプチドを迅速に化学合成 する方法が考案されてきました，現在では固相合成 技術が主流で，自動合成機が作ってくれます。一方 で, 二次代謝産物として扱われるペプチドは異常ア ミノ酸を含有するため天然物として扱われ，種々の バリエーションがあるため自動化には解決すべき課 題が残されています。そのためさまざまな有機合成 反応を駆使しながら液相法で全合成を目指すことに なります，筆者は両者のいいとこ取りで有用化合物 の創製が行えないか，という研究を展開しています。

（注釈）二次代謝産物

生物共通の生命現象に直接関与しない代謝経路に よって与えられる有機化合物のこと

Martinez 5
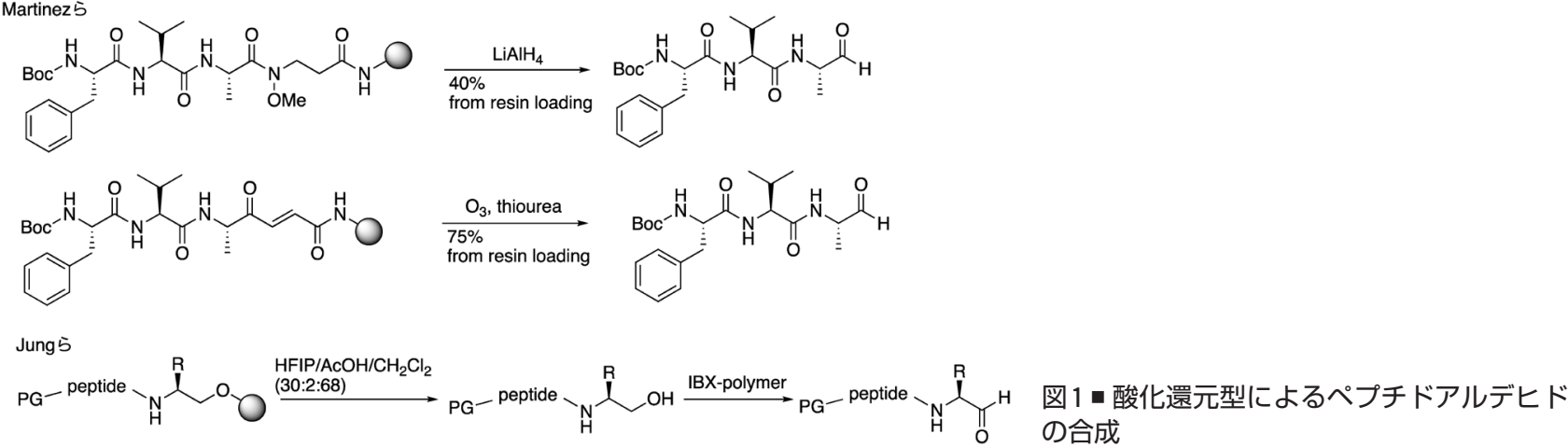

記，いずれの方法も簡便さから固相上での検討がなされ ている.

\section{1 酸化還元型によるペプチドアルデヒドの合成}

最も代表的な方法はWeinreb樹脂 ${ }^{(4)}$ 用いたもので あろう。本樹脂上で通常のペプチド合成を行い, $\mathrm{LiAlH}_{4}$ などの還元剤で樹脂から切り出すことでペプチドアルデ ヒドを得る方法である。また，アルデヒド前駆体をオレ フィンとして調製し，ペプチドの伸長後，オゾン分解を

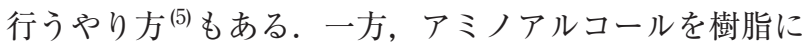
担持したのちにペプチドを伸長，樹脂からアルコールと して切断後, IBX 試薬などで酸化しペプチドアルデヒド
を得る方法がJungら (6)によって考案されている。これ らの方法は比較的単純なペプチドには適用可能である が，立体障害の大きな官能基を有するものや有機溶媒へ の溶解度が低いものなどではしばしば収率の低下を招 く．また酸化剤や還元剂に弱い配列（官能基）をもつ場 合には注意が必要となる（図1）。

\section{2 アルデヒド等価体型によるペプチドアルデヒドの 合成}

本方法はアミノ酸をいったんアミノアルデヒドにし， それをアセタール，セミカルバゾン，オキサゾリジンな どに変換後リンカーとして樹脂に担持する，そしてペプ 

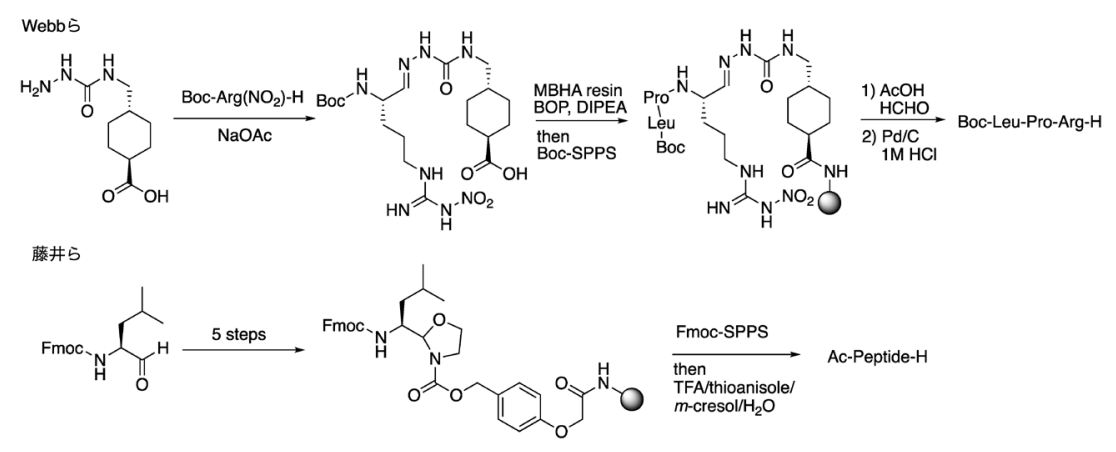

図2ロアルデヒド等価体型によるペプチドア ルデヒド合成法

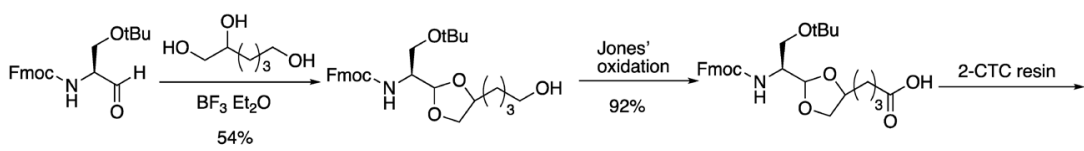

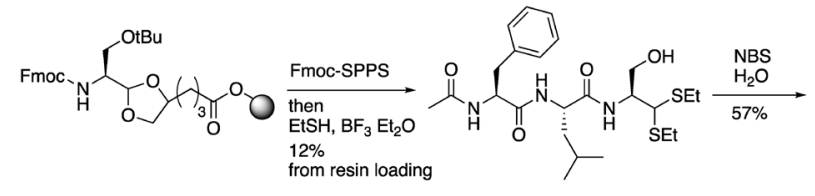

チド鎖の伸長後に樹脂からの切断を行う。この方法の特 徵は, 樹脂からの切り出しに, 通常のペプチドの切り出 しと同様TFA などの強酸を使用できることである。そ のため酸化還元法よりもリスクが少ない. 欠点は設計し たリンカーの合成が多段階になること, さらにそのペプ チド鎖伸長時に不安定になりやすいことが挙げられる.

代表的な例を紹介する. Webbら (7) はセミカルバゾン リンカーをヒドラジンから4工程で合成し, Boc-Arg $\left(\mathrm{NO}_{2}\right)$ - $\mathrm{H}$ を結合後, MBHA 樹脂に担持した. ペプチド の伸長後, アルデヒドへの変換は酶酸／ギ酸で行ってい る.また, 藤井ら ${ }^{(8)}$ はFmoc-Leu-Hから4工程でオキサ ゾリジンリンカーとして樹脂に担持し，ペプチド鎖伸長 反応に用いている．樹脂からの切り出しとアルデヒドへ の変換を TFA/thioanisol $/ m$-cresol $/ \mathrm{H}_{2} \mathrm{O}$ という通常のぺ プチド合成と同様の方法で行い，良好な結果を得ている (図2).

われわれのグループは，プロテアーゼ阻害剤開発に向 け効率的なペプチドアルデヒド合成法を模索していた. さまざまな誘導体合成に耐えうる方法論としてアルデヒ ド等価体型を採用したが, リンカーの選択に問題を抱え ていた，安定なぺプチド合成にはアセタールリンカーが 最も良い結果を与えたが, 最終段階でのTFA処理では 樹脂から 10\%程度しか切り出されず収率の向上が見达 めなかった，そこでアセタールをより温和な条件でアル デヒドに変換する方法を検討した．最終的にアセタール をいったんチオアセタールに変換することで効率的にペ プチドアルデヒドが得られることを見いだした。すなわ ちぺプチド鎖の伸長後に触媒量のルイス酸存在下 $\mathrm{EtSH}$

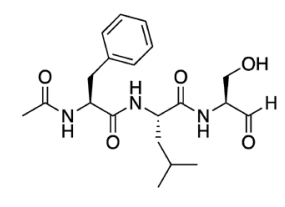

図3・チオアセタールを経由するペプチドア ルデヒド合成

を加えると，アセタール/チオアセタールの交換反応が スムーズに進行することがわかった，得られたぺプチド チオアセタールは, $\mathrm{NBS} / \mathrm{H}_{2} \mathrm{O}$ 処理により数秒から数分 でアルデヒドに変換された，反応終了後，すぐに後処理 を行うことでペプチドアルデヒドが合成できた ${ }^{(9)}$ ，その 後, さまざまな配列で本合成の適用限界を検討したとこ ろ, Trp, Cys, Metでは良好な収率を与えなかった ${ }^{(10)}$. 本方法論は，20種類のアミノ酸すべてに対応可能では なく, チオアセタールからの変換を手早く行う必要があ るが, 強酸を用いずに済むためさまざまな場面で活躍で きるかもしれない（図3）。

\section{異常アミノ酸含有環状デプシペプチドの合成}

\section{1. 環状デプシペプチド}

デプシペプチドとはエステル（デプシ）構造を分子内 にもつものであり, 数多く単離, 構造決定されている. ここでは抗HIV 活性を有する化合物に限って解説した い. 抗HIV 活性を有する環状デプシペプチドとして現 在までcallipeltin $\mathrm{A},{ }^{(11)}$ papuamide $\mathrm{B},{ }^{(12)}$ neamphamide $A,{ }^{(13)}$ mirabamide $A^{(14)}$, さらに比較的最近発見された homophymine $\mathrm{B}^{(15)}$ pipecolidepsin $\mathrm{A}^{(16)}$ とその類縁体が 知られている.これらはいずれも海綿から単離されてお り, 強力な抗 HIV 活性と細胞毒性を有している. また, 構造類似性が高いため, 活性発現には同じ標的部位に作 用していると考えられている. 構造的特徴としてデプシ 結合部位がD-スレオニン様アミノ酸側鎖とC末端カルボ ン酸であること, 近傍に diMeGln, $\mathrm{N}$ 末端に分岐脂肪酸 

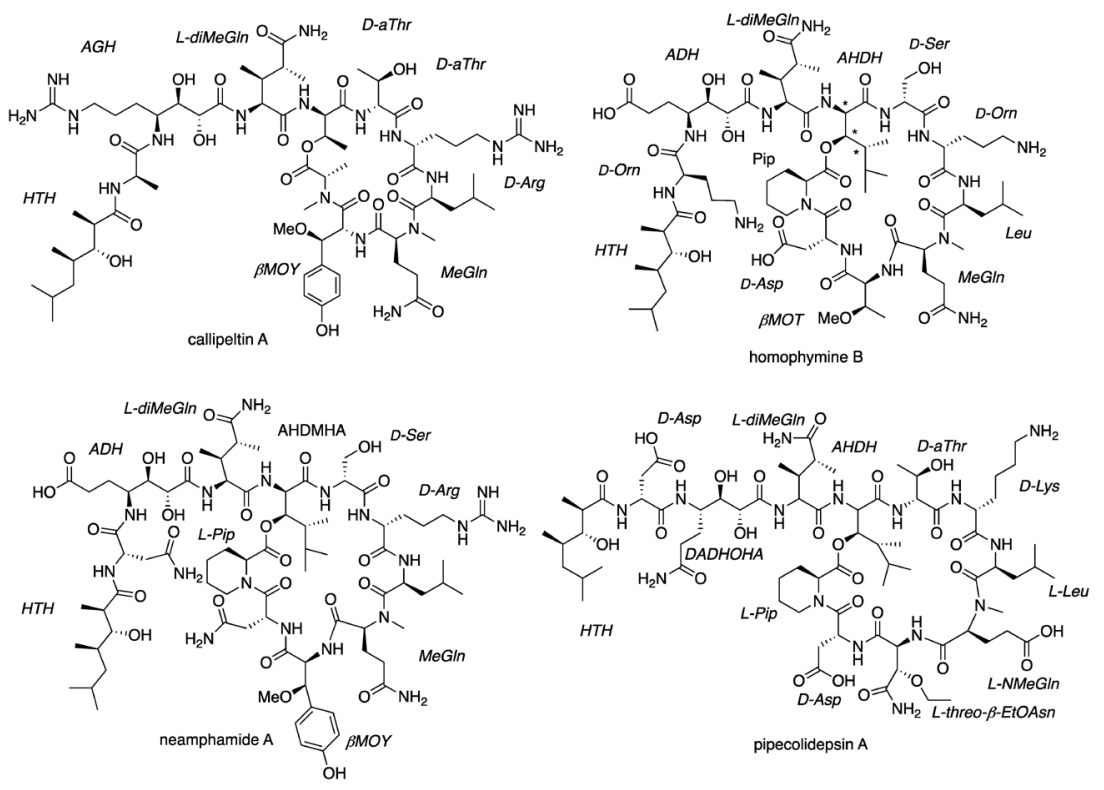

図4ロ抗HIV 活性を有する環状デプシペプチ
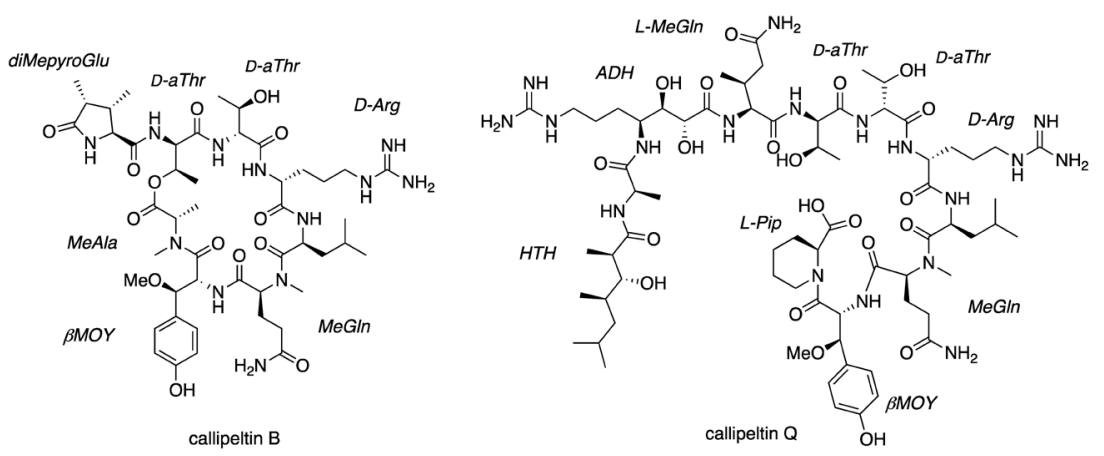

ド類

図5・Callipeltin Bならびに callipeltin Q

が結合していることがあげられる，環状部は7あるいは $8 つ の ア ミ ノ$ 酸残基で構成され, 直鎖部の $\mathrm{N}$ 末端には 3 残基のアミノ酸と脂肪酸側鎖が連結している.アミノ酸 としては, D-, $N-\mathrm{Me}$ ，さらに $\beta-, \gamma-ア ミ ノ$ 酸を豊富に含ん でいる．環状部に位置する $\beta$-メトキシアミノ酸が安定性 を欠くため, 構造決定や化学合成をより困難なものにし ている. そのため, 構造決定を目的としたものを含め構 成異常アミノ酸, 脂肪酸側鎖の立体制御合成は数多く報 告されているものの, 全合成例は少ない. 固相全合成の 達成はAlbericio ら ${ }^{(17)} の$ pipecolidepsin A, Lipton ら ${ }^{(18)} の$ callipeltin Bさらに筆者らの callipeltin $\mathrm{B}^{(19)}, \mathrm{Q}^{(20)}$ のみで ある。この種の化合物を合成するには構成異常アミノ酸 や側鎖脂肪酸を立体制御下に合成し，適切な保護基を導 入しておく必要がある。溶液中で収束的に合成するか, 固相上で直線的に行うかで用いる保護基を変えなければ ならない。一般的に通常の液相法ではBoc法（ただし， 側鎖保護基はさまざまである)，固相法ではFmoc法が 用いられることが多い. 以下，異常アミノ酸の立体制御
合成と固相全合成について解説したい（図 4, 5).

\subsection{Pipecolidepsin Aの全合成}

Pipecolidepsin A 2010 年に海綿 Homophymia lamellosaから単離され，2D-NMR, JBCA 法などを駆使した 構造決定が試みられたものの, 完全決定には至っていな かった. 2013年に Albericioらの全合成によって立体化 学を含む全構造が確定した、本全合成のポイントは環化 部位の選定とデプシ化のタイミングであった。その理由 としてデプシ結合周辺は立体障害が大きいアミノ酸が連 続しており反応性が極端に低いことが挙げられる。そこ でAlbericioらは環化部位をPip とAspとし, Aspの側 鎖を樹脂に担持することにした。 入手困難な Fmoc 異常 アミノ酸（DADHOHA, aAHDMHA）をアミノ酸誘導 体から立体制御下に液相合成した後，各Fmocアミノ酸 を N末端に向かって順次カップリングし diMeGlnまで 導入したところで，デプシ結合を介したAlloc-Pipの カップリングに成功している。 その後, DADHOHA, HTH-D-Asp を連結し全長とした。後半の伸長は繊細で, 

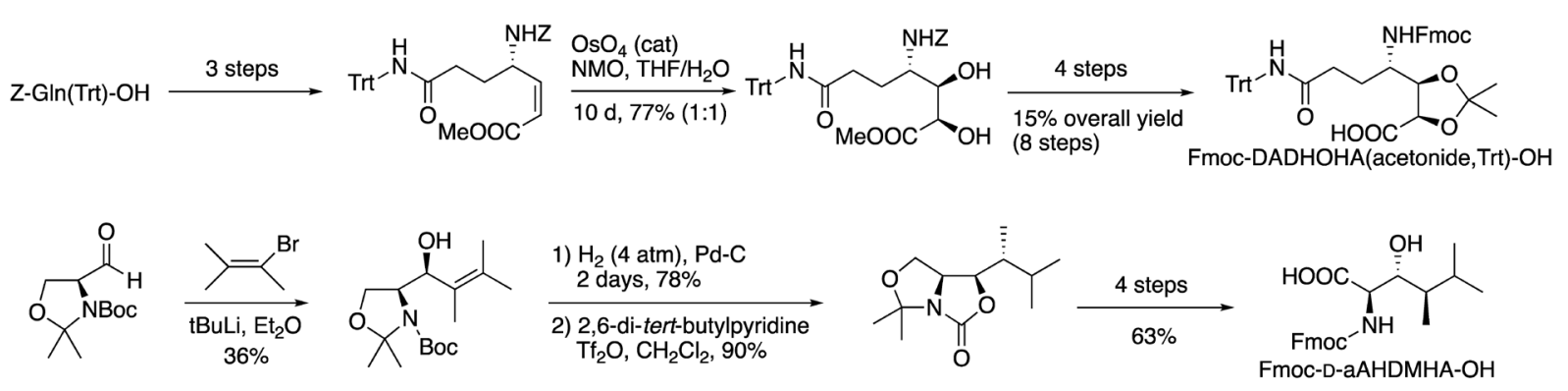

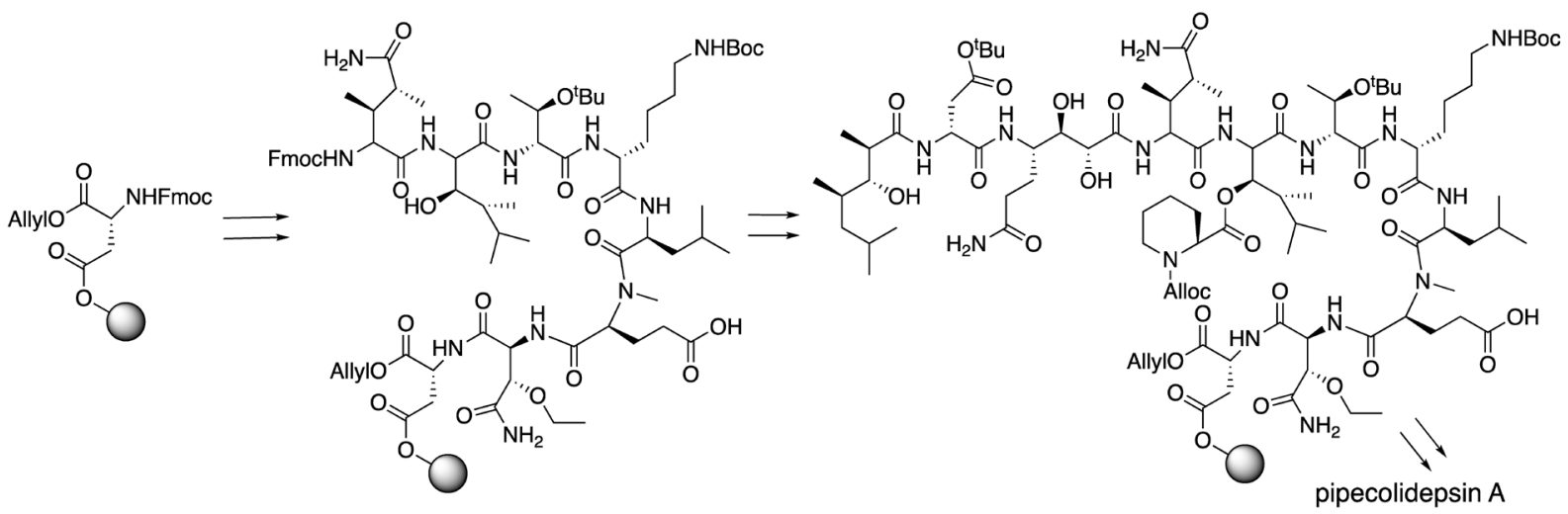

図6・Albericio らによる pipecolidepsin Aの固相全合成

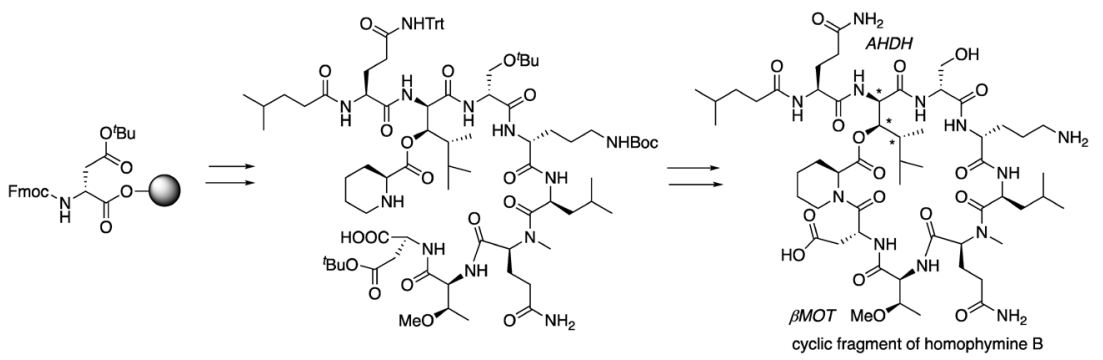

図7・Homophymine B 環状部の合成



図8・Lipton らによるcallipeltin Bの固相全 合成

カップリングの順番と詳細な条件検討により成功してい る。 その後の環化はPyBOP/HOAtで, 最終脱保護と樹 脂からの切り出しはTFAで行い pipecolidepsin Aの固 相全合成を達成した。その後の cancer cell linesに対す る細胞毒性試験において，DADHOHAの欠損がその活 性を極端に低下させることが示された（図6）.

筆者らはhomophymine Bの環状部合成において, pipecolidepsin Aの環状部形成と同様の課題を抱え, 結 果的にAlbericioらと同じ位置での環化条件が最も良い 結果を与えることを報告した ${ }^{(21)}$ (図7)。

\subsection{Callipeltin Bの全合成とアナログ合成}

Callipeltin Bは1996年, 海綿Callipelta sp. から単 離・構造決定された細胞毒性を有する環状デプシペプチ ドである. Callipeltin Bは分子内に酸性で加水分解しゃ すい $\beta$-methoxytyrosine $(\beta \mathrm{MOY})$ を含んでおり，その 立体化学は不明であった. Lipton らは callipeltin Bなら びにEの全合成によって, $\beta \mathrm{MOY}$ の立体化学と $2 つ の$ Thr D-aThrに改訂し全立体化学を決定した. 全合成 のポイントとして樹脂への担持を MeGln 側鎖で行って いること，環化位置を $\beta \mathrm{MOY}$ と MeAla 間のマクロラク 

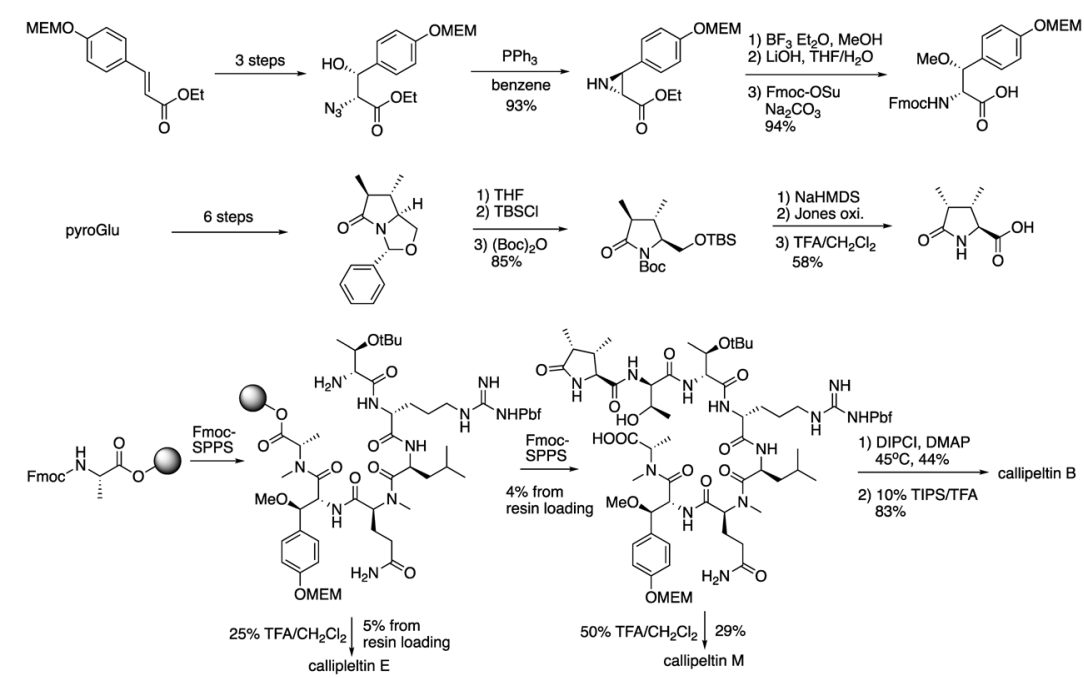
図9・われわれのグループによる callipeltin B
の全合成

夕ム化とし，側鎖保護基に $\mathrm{Bn}, \mathrm{NO}_{2}$, THPを用いている ことが挙げられる。一般的にエステル結合よりもアミド 結合が環化に有利なこと, 強酸を用いずに合成を進めら れることを念頭に行った，理にかなった戦略であること が伺われた（図8).

われわれの目的は構造活性相関研究であったため, 環 化部位を考慮する必要があった。そこで(1) 樹脂からの 切り出しと最終脱保護は最もオーソドックスなTFA で 行う（側鎖保護基に MEM, Pbf, tBuを選択した），(2） 環化はデプシ部分で行う（よって合成はC末端から始め る）という戦略を立てた.

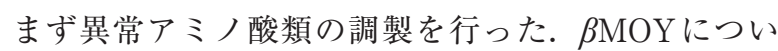
ては当初立体化学が不明であったため, 可能なジアステ レオマー4種を作り分けることにした。すなわちシンナ ミルエステル誘導体に対して Sharplessの不斉アミノヒ ドロキシ化と不斉ジヒドロキシ化を使い分けることで, 立体化学を制御した。またアンチ型の場合 $\beta$ 位のメトキ シ化が困難を極めたが，アジリジンを経由することで効 率的な合成法を開発することができた。得られた 4 種の $\beta \mathrm{MOY}$ に周辺アミノ酸であるGlnと MeAlaをカップリ ングし，それぞれトリペプチドに変換した。これらと天 然物とのスペクトルデータを比較し, $\beta \mathrm{MOY}$ の立体化 学を $2 R, 3 R$ と決定することができた。一方で, diMepyroGluの 4 種のジアステレオマーの合成にも成功し，天 然物の立体化学を確認した。

次にcallipeltin Bの部分構造をもつ callipeltin Eの全 合成を検討した，樹脂に2-CTC樹脂を用い， Fmoc 基の 除去は $20 \%$ piperidine/DMFで行った. 構成 Fmoc-アミ ノ酸のカップリングを最適化しながらペプチド鎖を伸長 した. 樹脂からの切り出しと保護基の除去は蒸留した TFAを用いたときにのみ効率よく進行した。各種スペ
クトルデータは文献と完全に一致したことから $\beta \mathrm{MOY}$, D-aThrの立体化学も確認することができた.さらに, Fmoc-D-aThr-OH と diMepyroGluを伸長し，脱保護する ことで callipeltin Mを得た。一方，保護基をつけたまま 分子内デプシ結合をDIPCI/DMAP条件で構築し, 最後 に10\% TIPS/TFAで処理することでcallipeltin Bの全 合成を達成した。環化をアミド結合で試みた場合はジケ トピペラジン形成が続発し，デプシ結合でのみ環化が可 能であると結論づけた。 さらに，さまざまなアナログ体 の合成にも応用することができた（図9).

\subsection{Callipeltin Bの細胞毒性試験とその改訂}

合成した callipeltin BはHela cell lineに対して全く毒 性を示さなかった. 単離されたcallipeltin $\mathrm{B}_{\text {は }} \mathrm{CC}_{50}=$ $20 \mu \mathrm{M}$ であったため,さまざまなデー夕の再取得を行 い, MALDI-TOFMSに合成物には見られないシグナル を見いだした。この結果は異なる物質の存在を示唆した ため, 詳細な NMR と MS 解析, さらにはHPLCでの分 離条件を検討し, callipeltin Cならびにcallipeltin $\mathrm{H}$ と 思われる物質を分離した。 これら天然物の細胞毒性は単 離 callipeltin Bと一致したことから，活性本体はcallipeltin Bではなく, callipeltin CならびにHであること を突き止めた。これらの結果は callipeltin類の天然物を 快く提供してくれたZampellaら単離グループの協力が あって初めて成し遂げられたことであることを申し添え たい. その後の構造活性相関研究によって, callipeltin 類の環状デプシペプチド部分ならびに鎖状部分だけでは 細胞毒性はなく, 全体の構造が重要であることがわかっ た。 また環状構造は活性をより強力にする(22) (図 10).

\subsection{Callipeltin Qの固相全合成}

Callipeltin Q 2016 年にTabudravuらの研究グルー プによって報告された新しい類縁体である(23). われわ 


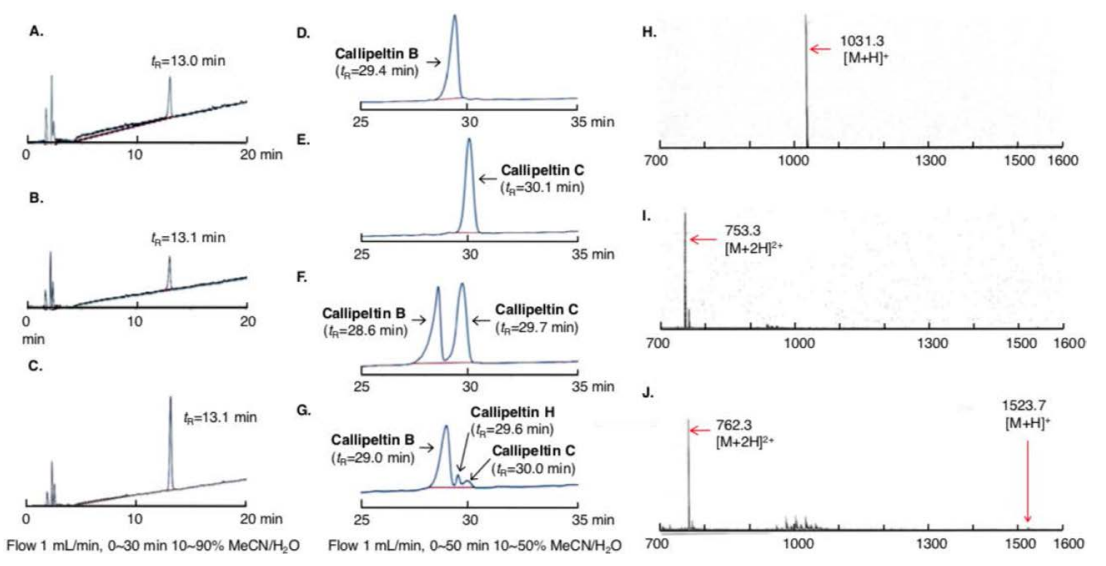

図 10 - Callipeltin B, C, HのHPLC (A-G) と ESIMSスペクトル (H-J)

(A) 合成 callipeltin B. (B) 天然 callipeltin B. (C) 天然callipeltin C. (D) 合成 callipeltin B. (E) 天 然callipeltin C. (F) 合成 callipeltin B と天然 callipeltin Cの混合物. (G) 天然callipeltin B. (H) 天 然callipeltin B. (H) 合成 callipeltin B. (I) callipeltin $\mathrm{H}$. ( $\mathrm{J}$ ) callipeltin $\mathrm{C}$.
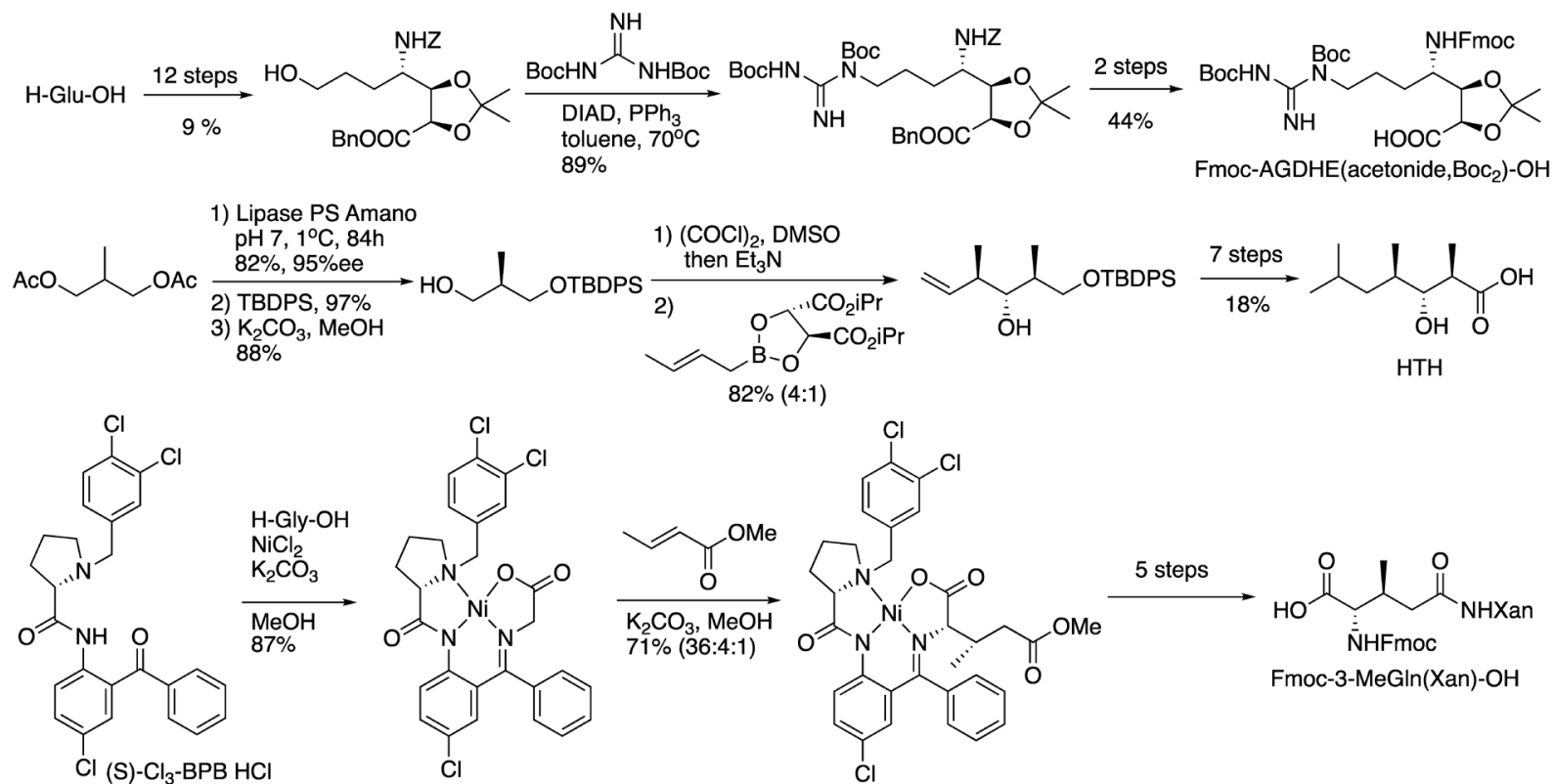<smiles>CN1C(=O)CN2C(c3ccccc3)=C3O[N+]4(N(Cc5ccc(Cl)c(Cl)c5)C(=O)[C@H]12)N(C(=O)[C@@H]1CCCN14)c1cc(Cl)ccc13</smiles><smiles>C/C=C/C(=O)OC</smiles>

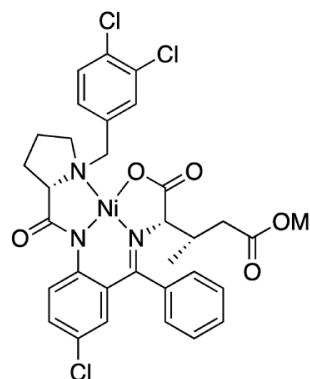

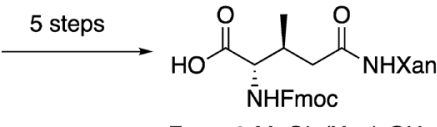

Fmoc-3-MeGln(Xan)-OH

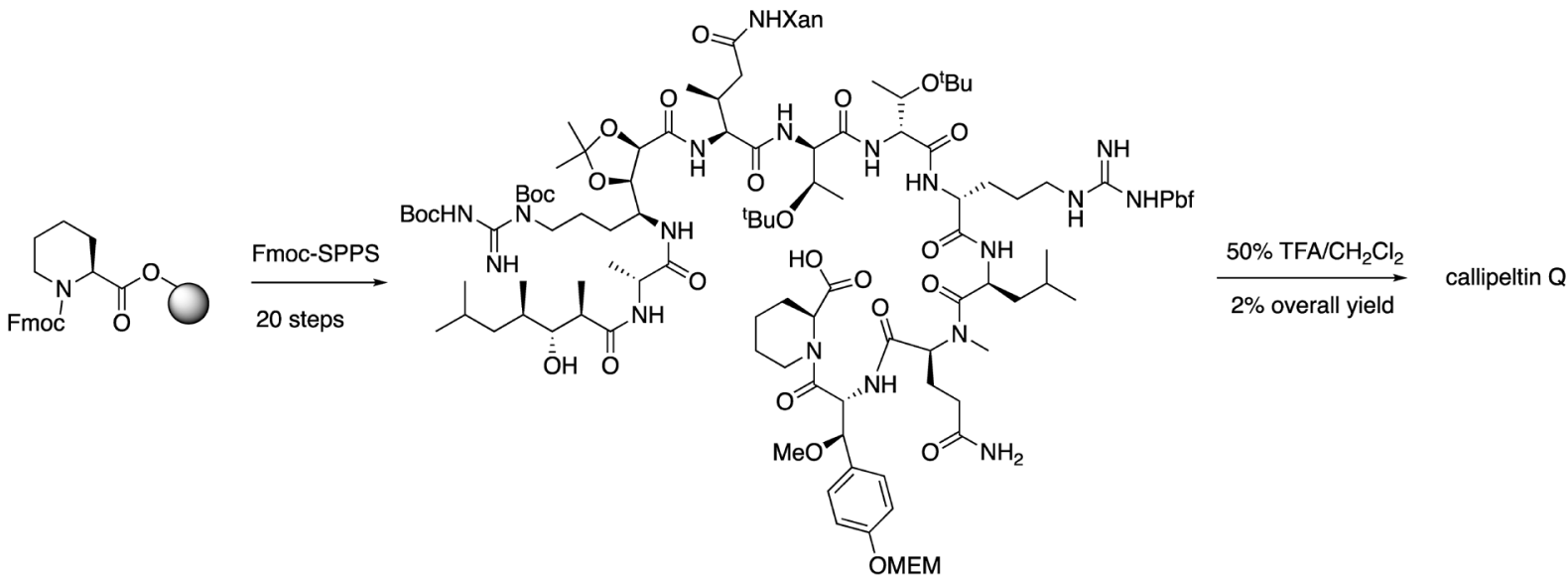

図 11 - Callipeltin Qの固相全合成

れは callipeltin Qの直鎖部を構成する3-MeGln, AGDHE, HTHの合成を行い， callipeltin Qの全合成に挑戦した. 3-MeGlnの合成ではSoloshonokらによって開発された
BPBリガンドを用いることでジアステレオ選択的に 3 位 メチル基の導入と側鎖にキサンチン（Xan）保護基の導 入を行った.AGDHE保護体は, H-Glu-OH から 15 工程 
で得ることに成功した．鍵反応として光延条件下でのグ アニジド基導入が挙げられる．HTHについては2-methyl-1,3-propanediol誘導体をリパーゼによって光学活性体 とし，その後，Roush不斉クロチル化を行ない合成し た．構成するすべてのアミノ酸，側鎖脂肪酸の入手に成 功したので，2-CTC樹脂上でカップリングと脱保護を逐 一条件検討しながら慎重に進めた。すべての構成成分を カップリング後, ペプチドを樹脂から HFIPで切り出 し，望む callipeltin $\mathrm{Q}$ 保護体を得ることに成功した．最 後に TFA ですべての保護基を除去することで callipeltin $\mathrm{Q}$ の固相全合成を達成することができた（図 11）.

以上のように異常アミノ酸含有ペプチドの合成には依 然として天然物合成化学の要素がふんだんに盛り込まれ て扔り, 精密な立体制御合成と詳細な構造解析, 生物活 性評価, さらには天然物と物性值や挙動の直接比較が必 要である。昔ながらの研究スタイルと言わざるを得ない が，それも異常アミノ酸含有ペプチドの魅力なのかもし れない，今回紹介した合成ではぺプチドの組立部分に関 しては固相上で行われており, 自動合成機の活用が期待 される. 迅速な構造活性相関研究が可能となれば創薬研 究がより加速する.

\section{おわりに}

以上，ペプチドアルデヒド合成と環状デプシペプチド 類の合成において，固相合成を用いた例を簡単に紹介し た．紙面の都合上，筆者らが手がけている研究を中心と したが，異常アミノ酸含有ペプチドを「天然物」ととら えて液相法で収束的合成を展開している研究者も抢り, その志向の違いが興味のもたれるところである.多くの 読者の方に興味をもっていただけると望外の喜びである.

\section{文献}

1) T. Aoyagi, T. Takeuchi, A. Matsuzaki, K. Kawamura, S Kondo, M. Hamada, K. Maeda \& H. Umezawa: J. Antibiot. (Tokyo), 22, 283 (1969).

2) H. Suda, T. Aoyagi, M. Hamada, T. Takeuchi \& H. Umezawa: J. Antibiot. (Tokyo), 25, 263 (1972).

3) K. J. Jensen \& J. Brask: J. Pept. Sci., 6, 290 (2000).

4) J.-A. Fehrentz, M. Paris, A. Heitz, J. Velek, C.-F. Liu, F. Winternitz \& J. Martinez: Tetrahedron Lett., 36, 7871 (1995).

5) C. Pothion, M. Paris, A. Heitz, J. Velek, C.-F. Liu, F. Fehrentz \& J. Martinez: Tetrahedron Lett., 38, 7749 (1997).

6) G. Sorg, B. Thern, O. Mader, J. Rademann \& G. Jung: J. Pept. Sci., 11, 142 (2005).

7) A. M. Murphy, R. Dagnino, P. L. Vallar, A. J. Trippe, S. L. Sherman, R. H. Lumpkin, S. Y. Tamura \& T. R. Webb: J. Am. Chem. Soc., 114, 3156 (1992).
8) M. Tanaka, S. Oishi, H. Ohno \& N. Fujii: Int. J. Pept. Res. Ther., 13, 271 (2007).

9) H. Konno, Y. Sema, M. Ishii, Y. Hattori, K. Nosaka \& K. Akaji: Tetrahedron Lett., 54, 4848 (2013).

10) H. Konno, Y. Sema \& Y. Tokairin: Tetrahedron, 71, 3433 (2015).

11) A. Zampella, M. V. D' Auria, L. G. Paloma, A. Casapullo, L. Minale, C. Debitus \& Y. Henin: J. Am. Chem. Soc., 118, 6202 (1996).

12) P. W. Ford, K. R. Gustafson, T. C. McKee, N. Shigematsu, L. K. Maurizi, L. K. Pannell, D. E. Williams, E. Dilip de Silva, P. Lassota, T. M. Allen et al.: J. Am. Chem. Soc., 121, 5899 (1999).

13) N. Oku, K. R. Gustafson, L. K. Cartner, J. A. Wilson, N. Shigematsu, S. Hess, K. L. Pannell, M. R. Boyd \& J. B. McMahon: J. Nat. Prod., 67, 1407 (2004).

14) A. Plaza, E. Gustchina, H. L. Baker, M. Kelly \& C. A. Bewley: J. Nat. Prod., 70, 1753 (2007).

15) A. Zampella, V. Sepe, P. Luciano, F. Bellotta, M. C. Monti, M. V. D' Auria, T. Jepsen, S. Petek, M.-T. Adeline, O. Laprevote et al.: J. Org. Chem., 73, 5319 (2008).

16) L. Coellp et al:: Int. Appl. Pat. WO 2010/070078 A1 (2010).

17) M. Pelay-Gimeno, Y. Garcia-Ramos, M. J. Martin, J. Spengler, J. M. Molina-Guijarro, S. Munt, A. M. Fracesch, C. Cuevas, J. Tulla-Puche \& F. Albericio: Nat. Commun., 4, 2352 (2013).

18) R. Krishnamoorthy, L. D. Vazquez-Serrano, J. A. Turk, J. A. Kowalski, A. G. Benson, N. T. Breaux \& M. A. Lipton: J. Am. Chem. Soc., 128, 15392 (2006).

19) M. Kikuchi \& H. Konno: Org. Lett., 16, 4324 (2014).

20) Y. Tokairin \& H. Konno: Manuscript in preparation.

21) Y. Tokairin, S. Takeda, M. Kikuchi \& H. Konno: Tetrahedron Lett., 56, 2809 (2015).

22) M. Kikuchi \& H. Konno: Biosci. Biotechnol. Biochem., 80 , 1066 (2016).

23) M. Stierhof, K. Q. Hansen, M. Sharma, K. Feussner, K. Subko, F. F. Diaz-Rullo, J. Isaksson, I. Perez-Victoria, D. Clarke, E. Hansen et al.: Tetrahedron, 72, 6929 (2016).

\section{プロフィール}

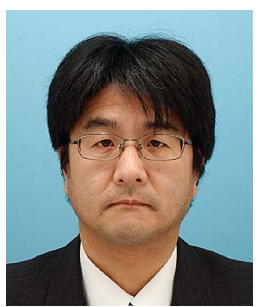

今野 博行 (Hiroyuki KONNO)

<略歴>1994年東北大学農学部農芸化学 科卒業/1996年同大学大学院農学研究科 農芸化学専攻修士課程修了／1999年同大 学大学院薬学研究科製薬化学専攻博士課程 修了／同年ペンシルベニア大学化学科博士 研究員 $/ 2000$ 年德島大学工学部生物工学 科助手 $/ 2004$ 年京都大学大学院薬学研究 科助手 /同年京都府立医科大学大学院医学 研究科助手 $/ 2009$ 年山形大学大学院理工 学研究科准教授 / 2018 年同教授, 現在に 至る<研究テーマと抱負 $>$ 天然物を基盤と した疾患関連タンパク質の阻害剂創製。世 の中に役立つ物質や方法論開発をしていき たいく趣味 $>$ 自転車と電車に乗ること

Copyright （C２０18 公益社団法人日本農芸化学会 DOI: 10.1271/kagakutoseibutsu.56.627 